\title{
An Antimalarial Benzylisoquinoline Alkaloid from the Rainforest Tree, Doryphora sassafras
}

Malcolm S. Buchanan, Rohan A. Davis, Sandra Duffy, Vicky M. Avery, and Ronald J. Quinn*

Eskitis Institute, Griffith University, Nathan, Queensland 4111, Australia

* To whom correspondence should be addressed. Tel. +61-7-3735-6000. Fax: +61-7-3735-6001. Email: r.quinn@griffith.edu.au. 
Mass-directed isolation of the $\mathrm{CH}_{2} \mathrm{Cl}_{2} / \mathrm{MeOH}$ extract of Doryphora sassafras resulted in the purification of a new benzylisoquinoline alkaloid, 1-(4-hydroxybenzyl)-6,7-methylenedioxy-2-methylisoquinolinium (1) and the known aporphine alkaloid (S)-isocorydine (2). The structures of $\mathbf{1}$ and $\mathbf{2}$ were determined by 1D and 2D NMR, and MS data analyses. The compounds were isolated during a drug discovery program aimed at identifying new antimalarial leads from a prefractionated natural product library. When tested against two different strains of the parasite Plasmodium falciparum (3D7 and Dd2), 1 displayed $\mathrm{IC}_{50}$ values of 3.0 and $4.4 \mu \mathrm{M}$, respectively. Compound $\mathbf{1}$ was tested for cytotoxicity towards the human embryonal kidney cell line (HEK293) and displayed no activity at $120 \mu \mathrm{M}$. 
Malaria is a major infectious disease caused by the protozoan parasite Plasmodium falciparum. Each year greater than 250 million clinical cases of malaria are reported with over 1 million of these cases resulting in death. ${ }^{1}$ Although several drugs are currently available for the treatment of malaria, the emergence of drug-resistant Plasmodium strains means that new therapies are urgently needed to treat this devastating disease. ${ }^{1}$

High-throughput screening (HTS) of a prefractionated natural product library has recently been undertaken at the Eskitis Institute in order to discover new antimalarial compounds. Two fractions derived from a leave extract of Doryphora sassafras (Monimiaceae), showed inhibitory activity in the malaria HTS assay, with no cytotoxicity identified towards the human embryonal kidney cell line (HEK293). MS analysis of the two active fractions identified ions in the (+)-LRESIMS at $m / z 294$ and 328, that were predicted to correspond to the bioactive natural products. Mass-directed isolation of the large-scale $\mathrm{CH}_{2} \mathrm{Cl}_{2} / \mathrm{MeOH}$ extract of $D$. sassafras afforded the new benzylisoquinoline alkaloid, 1-(4hydroxybenzyl)-6,7-methylenedioxy-2-methylisoquinolinium trifluoroacetate (1) and the TFA salt of the known aporphine alkaloid $(S)$-isocorydine (2). ${ }^{2-3}$ The genus Doryphora has previously yielded aporphines, isoquinolines, benzylisoquinolines, and bisbenzylisoquinolines. ${ }^{4-6}$ There have been reports of both synthetic and natural isoquinoline alkaloids with antimalarial activity. ${ }^{7-8}$ This paper reports the isolation, structure elucidation, and antimalarial activity of $\mathbf{1 .}$

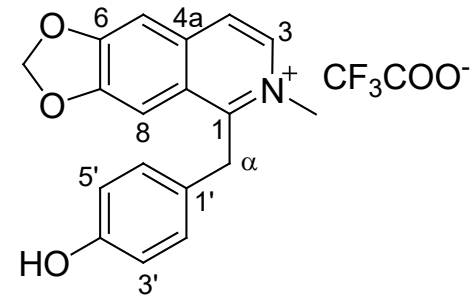

(1)

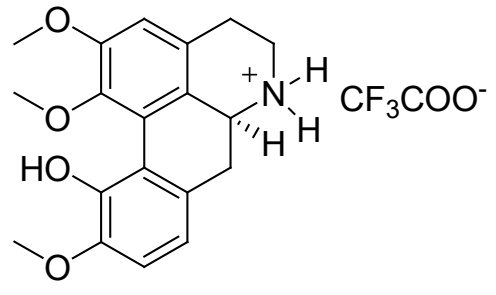

(2)

The $\mathrm{CH}_{2} \mathrm{Cl}_{2} / \mathrm{MeOH}$ extract from the dried and ground leaves of D. sassafras was initially chromatographed through polyamide gel. The resulting $\mathrm{MeOH}$ eluent was then purified by three steps of reversed-phase $\mathrm{C}_{18}$ HPLC to give the benzylisoquinoline alkaloid $\mathbf{1}$ and the aporphine alkaloid 2. 
Compound 1 was obtained as an optically inactive gum. The molecular formula for the free base of 1 was determined to be $\mathrm{C}_{18} \mathrm{H}_{16} \mathrm{NO}_{3}{ }^{+}$by (+)-HRESIMS on the $\left[\mathrm{M}-\mathrm{CF}_{3} \mathrm{COO}^{-}\right]^{+}$ion at $\mathrm{m} / z$ 294.1111. IR (3434, 1682, 1469, 1205, $\left.1133 \mathrm{~cm}^{-1}\right), \mathrm{UV}$ (strong absorption at $253 \mathrm{~nm}$ ), and NMR data (Table 1) indicated that 1 was a benzylisoquinoline derivative. Analysis of the ${ }^{1} \mathrm{H}$ NMR data suggested that the molecule contained a p-oxygenated phenyl group $[\delta \mathrm{H} 6.90 \mathrm{~d}(J=8.4 \mathrm{~Hz}) ; 6.70 \mathrm{~d}(J=8.4 \mathrm{~Hz})], \alpha$ and $\beta$ pyridine protons $\left[\delta_{\mathrm{H}} 8.52 \mathrm{~d}(J=7.2 \mathrm{~Hz}) ; 8.18 \mathrm{~d}(J=7.2 \mathrm{~Hz})\right]$, an $N$-methyl moiety $\left(\delta_{\mathrm{H}} 4.25\right)$, a methylenedioxy group $\left(\delta_{\mathrm{H}} 6.41\right)$, an $\alpha$-methylene moiety $\left(\delta_{\mathrm{H}} 4.84\right)$, two isolated aromatic proton $\left(\delta_{\mathrm{H}} 8.08\right.$ and 7.70) and a phenolic hydroxy group $\left(\delta_{\mathrm{H}}\right.$ 9.44). The correlations observed in the gHSQC and gHMBC spectra indicated that the molecule contained 16 unique carbons, which included two sets of coincident carbons that were associated with the $p$-oxygenated phenyl group. The gHSQC correlation between the two-proton singlet at $\delta_{\mathrm{H}} 6.41$ and the methylene carbon $\delta_{\mathrm{C}} 103.9$ support the presence of a methylenedioxy group. The methylenedioxy singlet at $\delta_{\mathrm{H}} 6.41$ showed gHMBC correlations to two downfield oxygenated aromatic carbons at $\delta_{\mathrm{C}} 151.8$ and 155.2. Correlations from the two aromatic singlets $\left(\delta_{\mathrm{H}} 8.08\right.$ and 7.70$)$ to the same oxygenated aromatic carbons indicated that these protons were ortho to the methylenedioxy group and para to each other. The singlet at $\delta_{\mathrm{H}} 7.70$ also showed a correlation to the $\beta$-pyridine carbon $\left(\delta_{\mathrm{C}} 122.3\right)$, thus indicating that an isoquinoline moiety was present in the compound. This was expanded to an $N$-methylisoquinolinium unit by gHMBC correlations from the $N$-methyl protons at $\delta_{\mathrm{H}} 4.25$ to the $\alpha$-pyridine carbons at $\delta_{\mathrm{C}} 155.7$ and 136.3. A two-proton singlet at $\delta_{\mathrm{H}} 4.84$ was assigned to the benzylic protons and showed gHMBC correlations to the carbons at $\delta_{\mathrm{C}} 128.8$ (2C) and 124.3 of the $p$-oxygenated phenyl group. These benzylic protons showed further gHMBC correlations to the $\alpha$ and $\beta$-pyridine carbons at $\delta_{\mathrm{C}} 155.7$ and 125.3 revealing the $p$-oxygenated benzyl group was attached to the isoquinoline moiety at C-1. In order to satisfy the molecular formula of $\mathbf{1}$ a $p$ hydroxy group was attached to C-4' $\left(\delta_{\mathrm{C}} 156.4\right)$ of the benzyl moiety. This was supported by gHMBC correlations from the exchangeable proton at $\delta_{H} 9.44$ to $\delta_{C} 156.4$ and $115.5(2 \mathrm{C})$. Therefore, compound 1 was assigned as 1-(4-hydroxybenzyl)-6,7-methylenedioxy-2-methylisoquinolinium trifluoroacetate. 
The related natural product, 2-methyl-1-( $p$-methoxybenzyl)-6,7-methylenedioxyisoquinolinium chloride, has been previously isolated from the leaves of a separate D. sassafras that was also collected in Queensland, Australia. ${ }^{6} \quad$ This 4-O-methyl analog of $\mathbf{1}$ had been previously reported to display weak activity in a $\kappa$ opioid receptor binding assay. Comparison of the NMR data of both these benzylisoquinoline alkaloids showed only minor differences. ${ }^{6}$

Compound 2 was identified as the TFA salt of the known aporphine alkaloid, $(S)$-isocorydine following comparison of the spectroscopic data with literature values. ${ }^{2-3}$

Table 2 shows the antimalarial activity for compounds $\mathbf{1}$ and $\mathbf{2}$ when tested against a chloroquine-sensitive (3D7) and a chloroquine-resistant (Dd2) Plasmodium falciparum strain. Preliminary toxicity towards human cells was also investigated for $\mathbf{1}$ and $\mathbf{2}$ using a human embryonal kidney cell line (HEK293). Neither compounds 1 or $\mathbf{2}$ showed any cytotoxicity towards the HEK293 cells up to $120 \mu \mathrm{M}$.

Table 2. Antimalarial and Cytotoxic Activity for Compounds $\mathbf{1}$ and $\mathbf{2 .}$

\begin{tabular}{ccccc}
\hline \multirow{2}{*}{ Compound } & \multicolumn{3}{c}{$\mathrm{IC}_{50}(\mu \mathrm{M})$} & Selectivity Index \\
& $\mathrm{Dd} 2$ & $3 \mathrm{D} 7$ & HEK293 & \\
\hline $\mathbf{1}$ & 4.4 & 3.0 & $0 \% @ 120 \mu \mathrm{M}$ & $>27(\mathrm{Dd} 2),>40(3 \mathrm{D} 7)$ \\
$\mathbf{2}$ & 19.0 & 17.0 & $0 \% @ 120 \mu \mathrm{M}$ & $>6(\mathrm{Dd} 2 / 3 \mathrm{D} 7)$ \\
Artemisinin $^{a}$ & 0.021 & 0.021 & $0 \% @ 2 \mu \mathrm{M}$ & $>100(\mathrm{Dd} 2 / 3 \mathrm{D} 7)$ \\
Chloroquine $^{a}$ & 0.130 & 0.025 & $0 \% @ 2 \mu \mathrm{M}$ & $>16(\mathrm{Dd} 2),>80(3 \mathrm{D} 7)$ \\
\hline
\end{tabular}

${ }^{a}$ If artemisinin and chloroquine were screened at a higher concentration the selectivity index would be much larger. ${ }^{9}$

\section{Experimental Section}

General Experimental Procedures. UV and IR spectra were recorded on an Agilent $8453 \mathrm{UV} / \mathrm{vis}$ spectrophotometer (Agilent, Santa Clara, CA, USA) and a Bruker Tensor 27 FTIR spectrophotometer 
(Bruker, Karlsruhe, Germany), respectively. NMR spectra were recorded at $30^{\circ} \mathrm{C}$ on Varian INOVA 500 and $600 \mathrm{MHz}$ NMR spectrometers (Varian, Walnut Creek, CA, USA). . The latter spectrometer was equipped with a triple resonance cold probe. The ${ }^{1} \mathrm{H}$ and ${ }^{13} \mathrm{C}$ NMR chemical shifts were referenced to the solvent peak for DMSO- $d_{6}$ at $\delta_{\mathrm{H}} 2.49$ and $\delta_{\mathrm{C}} 39.5$. Standard parameters were used for the 2D experiments, which included gradient gCOSY, gHSQC $\left({ }^{1} J_{\mathrm{CH}}=140 \mathrm{~Hz}\right)$ and $\mathrm{gHMBC}\left({ }^{\mathrm{n}} J_{\mathrm{CH}}=8.3 \mathrm{~Hz}\right)$. LRESIMS were recorded on a Waters ZQ mass spectrometer (Waters, Milford, MA, USA). HRESIMS were measured on a Bruker Daltonics Apex III 4.7e Fourier Transform Mass Spectrometer (Bruker, Karlsruhe, Germany), fitted with an Apollo API source. A BIOLINE orbital shaker (Edwards Instrument Company, Narellan, NSW, Australia) was used for the large-scale extraction of plant material. A ThermoElectron $\mathrm{C}_{18}$ Betasil $5 \mu \mathrm{m} 143 \AA$ column $(21.2 \mathrm{~mm} \times 150 \mathrm{~mm})$ (Thermo Scientific, Los Angeles, CA, USA) was used for semi-preparative HPLC. A Waters 600 pump fitted with a 996 Photodiode Array Detector and 717 plus Autosampler (Waters, Milford, MA, USA) was used for the semipreparative HPLC separations. End-capped Sepra $\mathrm{C}_{18}$ bonded silica (Phenomenex, Torrance, CA, USA) was used for pre-adsorption work. Machery Nagel Polyamide CC6 (0.05-0.016 mm) was used for tannin/polyphenolic removal (Machery Nagel, Düren, Germany). Water was Millipore Milli-Q PF (Millipore, Billerica, MA, USA) filtered, while all other solvents used were Lab-Scan HPLC grade (RCI Lab-Scan, Bangkok, Thailand). Parasite strains 3D7 and Dd2 were from the Queensland Institute of Medical Research. O+ Erythrocytes were obtained from the Australian Red Cross Blood Service. Cell Carrier polylysine coated imaging plates were from PerkinElmer (PerkinElmer, Waltham, MA, USA). 4',6-Diamidino-2-phenylindole (DAPI) stain and Alamar Blue were from Invitrogen (Invitrogen, Carlsbad, CA, USA). Triton-X, saponin, puromycin, and artemisinin were all from Sigma Aldrich (Sigma-Aldrich, St. Louis, MO, USA). HEK 293 cells were purchased from the American Tissue Culture Collection (ATCC, Manassa, VA, USA). The 384-well Falcon sterile tissue culture treated plates were from BD (BD, Franklin Lakes, NJ, USA). 
Plant Material. The leaves of D. sassafras Endlicher (Monimiaceae) were collected during August of 1994 from The Head, 1.5 km NW of Wilsons Peak, Darling Downs, Queensland, Australia. A voucher specimen (No. 601204) has been lodged at the Queensland Herbarium.

Extraction and Isolation. The freeze-dried and ground plant material $(10 \mathrm{~g})$ was poured into a conical flask (1L), $n$-hexane $(250 \mathrm{~mL})$ was added and the flask was shaken at $200 \mathrm{rpm}$ for $2 \mathrm{~h}$. The $n$-hexane extract was filtered under gravity then discarded. $\mathrm{CH}_{2} \mathrm{Cl}_{2}(250 \mathrm{~mL})$ was added to the de-fatted plant material in the conical flask and shaken at $200 \mathrm{rpm}$ for $2 \mathrm{~h}$. The resulting extract was filtered under gravity, and set aside. $\mathrm{MeOH}(250 \mathrm{~mL})$ was added and the $\mathrm{MeOH} / \mathrm{plant}$ mixture was shaken for a further $2 \mathrm{~h}$ at $200 \mathrm{rpm}$. Following gravity filtration the plant material was extracted with another

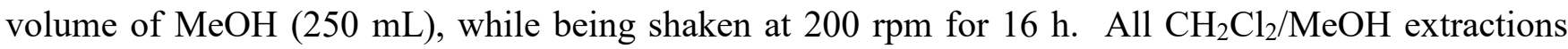
were combined and dried under reduced pressure to yield a crude extract $(1.32 \mathrm{~g})$. This material was resuspended in $\mathrm{MeOH}(150 \mathrm{~mL})$, loaded onto a $\mathrm{MeOH}$ conditioned polyamide gel $(30 \mathrm{~g})$ column and washed with $\mathrm{MeOH}(300 \mathrm{~mL})$. The resulting $\mathrm{MeOH}$ eluent $(0.97 \mathrm{~g})$ was pre-adsorbed on $\mathrm{C}_{18}$-bonded silica, then packed into a stainless steel cartridge $(10 \times 30 \mathrm{~mm})$ that was subsequently attached to a $\mathrm{C}_{18}$ semi-preparative HPLC column. Isocratic HPLC conditions of $90 \% \mathrm{H}_{2} \mathrm{O}(0.1 \%$ TFA $) / 10 \% \mathrm{MeOH}$ $(0.1 \%$ TFA $)$ were employed for the first $10 \mathrm{~min}$, then a linear gradient to $100 \% \mathrm{MeOH}(0.1 \% \mathrm{TFA})$ was run over $40 \mathrm{~min}$, followed by isocratic conditions of $100 \% \mathrm{MeOH}(0.1 \% \mathrm{TFA})$ for a further $10 \mathrm{~min}$, all at a flow rate of $9 \mathrm{~mL} / \mathrm{min}$. Sixty fractions $(60 \times 1 \mathrm{~min})$ were collected from time $=0 \mathrm{~min}$ and analysed by $(+)$-LRESIMS. Fractions $24-29(\mathrm{~m} / \mathrm{z} 294)$ and $30-33(\mathrm{~m} / \mathrm{z} 328)$ contained the ions of interest and were combined (98.5 and $21 \mathrm{mg}$, respectively) before undergoing further $\mathrm{C}_{18}$ HPLC. Fractions 24-29 (98.5 mg): A linear gradient from $100 \% \mathrm{H}_{2} \mathrm{O}\left(0.1 \%\right.$ TFA) to $60 \% \mathrm{H}_{2} \mathrm{O}(0.1 \%$ TFA $) / 40 \% \mathrm{MeOH}(0.1 \%$ TFA) was employed for $45 \mathrm{~min}$, followed by a linear gradient to $100 \% \mathrm{MeOH}(0.1 \% \mathrm{TFA})$ was run over $15 \mathrm{~min}$, at a flow rate of $10 \mathrm{~mL} / \mathrm{min}$. Sixty fractions $(60 \times 1 \mathrm{~min})$ were collected from time $=0 \mathrm{~min}$ and analysed by $(+)$-LRESIMS. Fraction 29 contained the ion of interest $(\mathrm{m} / \mathrm{z} 294)$ and required final purification by $\mathrm{C}_{18} \mathrm{HPLC}(3.6 \mathrm{mg})$. A linear gradient from $90 \% \mathrm{H}_{2} \mathrm{O}(0.1 \% \mathrm{TFA}) / 10 \% \mathrm{MeOH}(0.1 \%$ TFA) to $85 \% \mathrm{H}_{2} \mathrm{O}(0.1 \% \mathrm{TFA}) / 15 \% \mathrm{MeOH}(0.1 \% \mathrm{TFA})$ was employed for $1 \mathrm{~min}$, followed by isocratic 
conditions for $19 \mathrm{~min}$, then a linear gradient to $65 \% \mathrm{H}_{2} \mathrm{O}(0.1 \%$ TFA $) / 35 \% \mathrm{MeOH}(0.1 \%$ TFA) in 30 min and finally a linear gradient to $100 \% \mathrm{MeOH}(0.1 \% \mathrm{TFA})$ in $10 \mathrm{~min}$, at a flow rate of $10 \mathrm{~mL} / \mathrm{min}$. Sixty fractions $(60 \times 1 \mathrm{~min})$ were collected from time $=0 \mathrm{~min}$ and analysed by $(+)$-LRESIMS. Fractions 30-31 contained the compound of interest $(\mathrm{m} / \mathrm{z} 294)$, and following lyophilisation yielded 1-(4hydroxybenzyl)-6,7-methylenedioxy-2-methylisoquinolinium trifluoroacetate (1, $0.8 \mathrm{mg}, 0.008 \%$ dry wt). Further purification of fractions $30-33(21 \mathrm{mg})$ from the first $\mathrm{C}_{18}$ fractionation step, was undertaken using the following HPLC conditions: A linear gradient from $100 \% \mathrm{H}_{2} \mathrm{O}\left(0.1 \%\right.$ TFA) to $85 \% \mathrm{H}_{2} \mathrm{O}$ $(0.1 \% \mathrm{TFA}) / 15 \% \mathrm{MeOH}(0.1 \% \mathrm{TFA})$ was employed for $2 \mathrm{~min}$, followed by isocratic conditions for 23 min, then a linear gradient to $70 \% \mathrm{H}_{2} \mathrm{O}(0.1 \% \mathrm{TFA}) / 30 \% \mathrm{MeOH}(0.1 \% \mathrm{TFA})$ was run over $20 \mathrm{~min}$, and finally a linear gradient to $100 \% \mathrm{MeOH}(0.1 \% \mathrm{TFA})$ in $10 \mathrm{~min}$, at a flow rate of $10 \mathrm{~mL} / \mathrm{min}$. Sixty fractions $(60 \times 1 \mathrm{~min})$ were collected from time $=0 \mathrm{~min}$ and analysed by $(+)$-LRESIMS. Fraction 36 contained the compound of interest $(\mathrm{m} / \mathrm{z} 328)$, and following lyophilisation yielded the trifluroactetate salt of $(S)$-isocorydine $(2,1.6 \mathrm{mg}, 0.016 \%$ dry $w \mathrm{t})$.

1-(4-Hydroxybenzyl)-6,7-methylenedioxy-2-methylisoquinolinium trifluoroacetate (1): isolated as a gum; UV (MeOH) $\lambda_{\max }(\log \varepsilon) 326$ sh (3.57), $332 \mathrm{sh}$ (3.31), 313 (3.43), 283 (3.39), 253 (4.15), 228 (3.91) nm; IR $v_{\max }\left(\right.$ film) 3434, 1682, 1469, 1205, $1133 \mathrm{~cm}^{-1} ;{ }^{1} \mathrm{H}$ and ${ }^{13} \mathrm{C}$ NMR, see Table 1; (+)-

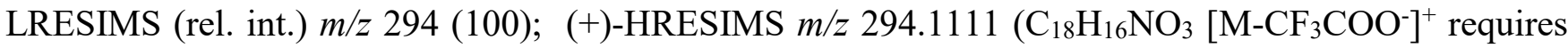
$294.1125, \Delta 4.8 \mathrm{ppm})$.

Antimalarial Assay. Compounds were incubated in the presence of 2 or $3 \%$ parasitemia (3D7 or $\mathrm{Dd} 2$ ) and $0.3 \%$ hematocrit in a total assay volume of $50 \mu \mathrm{L}$, for $72 \mathrm{~h}$ at $37{ }^{\circ} \mathrm{C}$ and $5 \% \mathrm{CO}_{2}$, in poly- $D$ lysine coated CellCarrier Imaging plates. After incubation plates were stained with DAPI in the presence of saponin and Triton X-100 and incubated for a further $5 \mathrm{~h}$ at $\mathrm{rt}$ in the dark before imaging on the Evotec OPERA ${ }^{\text {TM }}$ HTS confocal imaging system (PerkinElmer, Waltham, MA, USA). The digital images obtained were analysed using the Perkin Elmer Acapella spot detection software where 
fluorescent spots which fulfill the criteria established for a stained parasite are counted. The \% inhibition of parasite replication was calculated using DMSO and $2 \mu \mathrm{M}$ artemisinin control data.

Cytotoxicity Assay. Compounds were added to Falcon 384 well black/clear tissue treated assay plates containing 3000 adherent cells/well (HEK 293) in an assay volume of $45 \mu \mathrm{L}$. The plates were incubated for $72 \mathrm{~h}$ at $37{ }^{\circ} \mathrm{C}$ and $5 \% \mathrm{CO}_{2}$. After incubation the supernatant was aspirated out of the wells and 40 $\mu \mathrm{L}$ of $10 \%$ Alamar Blue added per well. Plates were incubated for a further 5-6 h and measured for fluorescence at $535 \mathrm{~nm}$ excitation and $590 \mathrm{~nm}$ emission using a VICTOR II (PerkinElmer, Waltham, MA, USA). The \% inhibition of cell growth was calculated using DMSO and $10 \mu \mathrm{M}$ puromycin control data. $\mathrm{IC}_{50}$ values were obtained by plotting \% inhibition against log dose using Prizm4 graphing package and non-linear regression with variable slope plot.

Acknowledgment. The authors would like to acknowledge Medicines for Malaria Venture for financial support. We thank $\mathrm{H}$. The $\mathrm{Vu}$ from Griffith University for acquiring the HRESIMS measurements. The authors thank D. Camp, C. Lewis and K. Watts from the Molecular Libraries group (Eskitis Institute) for their assistance in the preparation of the screening library. We thank B. Aldred and R. Lang for technical assistance with the HTS. We also wish to thank P. I. Forster and G. P. Guymer for the collection and taxonomic identification of the plant material. We also acknowledge the Australian Red Cross Blood Service for the provision of Type O+ erythrocytes and K. Andrews, QIMR for P. falciparum strains.

Supporting Information Available: NMR spectra for 1-(4-hydroxybenzyl)-6,7methylenedioxy-2-methylisoquinolinium trifluoroacetate (1). This material is available free of charge via the Internet at http://pubs.acs.org.

\section{References and Notes}


(1) Medicines for Malaria Venture, http://www.mmv.org/.

(2) Marsaioli, A. J.; Reis, F. De. A. M.; Magalhães, A. F.; Rúveda, E. A. Phytochemistry 1979, 18, 165-169.

(3) Dictionary of Natural Products on CD-Rom, version 17.2, Chapman and Hall / CRC Press: London, UK, 2009.

(4) Bick, I. R. C.; Leow, H.-M.; Richards, M. J. Aust. J. Chem. 1980, 33, 225-228.

(5) Chen, C. R.; Beal, J. L.; Doskotch, R. W.; Mitscher, L. A.; Svoboda, G. H. Lloydia 1974, 37, 493-500.

(6) Carroll, A. R.; Davis, R. A.; Forster, P. I.; Guymer, G. P.; Quinn, R. J. J. Nat. Prod. 2001, 64, $1572-1573$.

(7) Hallock, Y. F.; Cardellina II, J. H.; Schäffer, M.; Stahl, M.; Bringmann, G.; François, G.; Boyd, M. R. Tetrahedron 1997, 53, 8121-8128.

(8) Parai, M. K.; Panda, G.; Srivastava, K.; Puri, S. K. Bioorg. Med. Chem. Lett. 2008, 18, 776-781.

(9) Fernandez, L. S.; Buchanan, M. S.; Carroll, A. R.; Feng, Y. J.; Quinn, R. J.; Avery, V. M. Org. Lett. 2009, 11, 329-332. 
Table 1. ${ }^{1} \mathrm{H}(600 \mathrm{MHz})$ and ${ }^{13} \mathrm{C}(150 \mathrm{MHz}) \mathrm{NMR}$ data for Compound $\mathbf{1}$ in DMSO-d 6

\begin{tabular}{|c|c|c|}
\hline Position & $\delta_{\mathrm{C}^{a}}$ & $\delta_{\mathrm{H}} \operatorname{mult}(J$ in $\mathrm{Hz})$ \\
\hline 1 & $155.7 \mathrm{C}$ & \\
\hline $2-\mathrm{CH}_{3}$ & $45.4 \mathrm{CH}_{3}$ & $4.25 \mathrm{~s}$ \\
\hline 3 & $136.3 \mathrm{CH}$ & $8.52 \mathrm{~d}(7.2)$ \\
\hline 4 & $122.3 \mathrm{CH}$ & $8.18 \mathrm{~d}(7.2)$ \\
\hline $4 a$ & $137.7 \mathrm{C}$ & \\
\hline 5 & $103.2 \mathrm{CH}$ & $7.70 \mathrm{~s}$ \\
\hline 6 & $155.2 \mathrm{C}$ & \\
\hline $6,7-\mathrm{OCH}_{2} \mathrm{O}$ & $103.9 \mathrm{CH}_{2}$ & $6.41 \mathrm{~s}$ \\
\hline 7 & $151.8 \mathrm{C}$ & \\
\hline 8 & $103.3 \mathrm{CH}$ & $8.08 \mathrm{~s}$ \\
\hline $8 \mathrm{a}$ & $125.3 \mathrm{C}$ & \\
\hline$\alpha$ & $33.1 \mathrm{CH}_{2}$ & $4.84 \mathrm{~s}$ \\
\hline $1^{\prime}$ & $124.3 \mathrm{C}$ & \\
\hline $2^{\prime}$ & $128.8 \mathrm{CH}$ & $6.90 \mathrm{~d}(8.4)$ \\
\hline $3^{\prime}$ & $115.5 \mathrm{CH}$ & $6.70 \mathrm{~d}(8.4)$ \\
\hline $4^{\prime}$ & $156.4 \mathrm{C}$ & \\
\hline 4'-OH & & $9.44 \mathrm{~s}$ \\
\hline $5^{\prime}$ & $115.5 \mathrm{CH}$ & $6.70 \mathrm{~d}(8.4)$ \\
\hline $6^{\prime}$ & $128.8 \mathrm{CH}$ & $6.90 \mathrm{~d}(8.4)$ \\
\hline
\end{tabular}

${ }^{a}$ Chemical shifts obtained from 2D NMR experiments. 


\section{Table of Contents Graphic}

An Antimalarial Benzylisoquinoline Alkaloid from the Rainforest Tree, Doryphora sassafras

Malcolm S. Buchanan, Rohan A. Davis, Sandra Duffy, Vicky M. Avery and Ronald J. Quinn

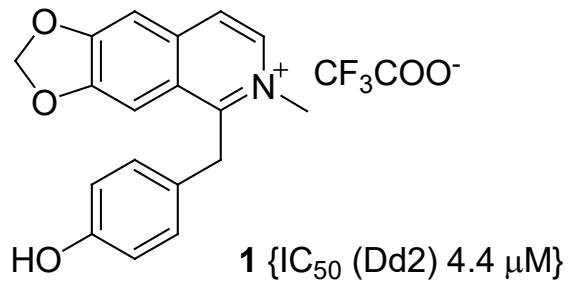

